\title{
Synthesis and biological evaluation of boronic acid-containing phenstatin analogues
}

\author{
Hiroyuki Nakamura,* Hirokazu Kuroda, and Hidemitsu Minegishi \\ Department of Chemistry, Faculty of Science, Gakushuin University, \\ 1-5-1 Mejiro, Toshima-ku, Tokyo 171-8588, Japan \\ E-mail: hiroyuki.nakamura@gakushuin.ac.jp
}

\section{Dedicated to Professor Keith Smith on the occasion of his 65th anniversary}

\begin{abstract}
A series of boronic acid-containing benzophenones was synthesized by introducing a boronic acid as an acceptor-type functional group into the aromatic ring B of the phenstatin skeleton. Among the compounds synthesized, $4 \mathbf{c}$ in which a hydroxyl group on the aromatic ring B of the phenstatin was replaced by a boronic acid, exhibited significant cell growth inhibition and the $\mathrm{GI}_{50}$ values toward B-16 and 1-87 cell lines are $0.013 \mu \mathrm{M}$ and $0.087 \mu \mathrm{M}$, respectively.
\end{abstract}

Keywords: Boronic acid, phenstatin, cell growth inhibition, benzophenone

\section{Introduction}

Combretastatin A-4 (1a) was isolated by Pettit and coworkers from the stem wood of the South African tree Combretum caffrum in 1982. ${ }^{1}$ This compound is one of the most potent antimitotic agents and exhibits potent cytotoxicity against a wide variety of human cancer cells including multidrug resistant cancer cell lines. ${ }^{2}$ Phenstatin (2a) is a synthetic tubulin assembly inhibitor developed by the same research group in $1998 .{ }^{3}$ This compound is a benzophenone-type molecule and the functional groups on the two phenyl rings are similar to combretastatin A-4. ${ }^{4}$ Based on the structures of both lead compounds, various benzophenone derivatives have been developed including aminobenzophenones (2b-c) $)^{5,6}$ and isocombretastatin A (3). ${ }^{7}$ These analogues have a donor-type functional group, as a common feature, substituted on the aromatic ring B (Figure 1). We are interested in introducing boronic acid as an acceptor-type functional group into the aromatic ring $\mathrm{B}$ in the phenstatin skeleton.

A boron atom has a vacant orbital and interconverts with ease between the neutral $\mathrm{sp}^{2}$ and the anionic $\mathrm{sp}^{3}$ hybridization states, which generates a new stable interaction between a boron atom 
and a donor molecule through a covalent bond. ${ }^{8}$ Therefore, it is expected that the boron atoms introduced into biologically active molecular frameworks would interact with a target protein not only through hydrogen bonds but also through covalent bonds, and this interaction might produce a potent biological activity. ${ }^{9}$<smiles>[R]c1cc(/C=C\c2ccc(OC)c(OC)c2)ccc1OC</smiles>

1a: $\mathrm{R}=\mathrm{OH}$, combretastatin $\mathrm{A}-4$ 1b: $\mathrm{R}=\mathrm{NH}_{2}$, AVE-8063

1c: $\mathrm{R}=\mathrm{NH}-\mathrm{Ser} \mathrm{HCl}$ salt, AVE-8062 1d: $\mathrm{R}=\mathrm{B}(\mathrm{OH})_{2}$<smiles>[R]c1c(OC)ccc(C(=O)c2cc(OC)c(OC)c(OC)c2)c1[R]</smiles>

2a: $\mathrm{R}^{1}=\mathrm{H}, \mathrm{R}^{2}=\mathrm{OH}$, phenstatin

2b: $\mathrm{R}^{1}=\mathrm{NH}_{2}, \mathrm{R}^{2}=\mathrm{H}, 2$-aminobenzophenone

2c: $\mathrm{R}^{1}=\mathrm{H}, \mathrm{R}^{2}=\mathrm{NH}_{2}$, 3-aminobenzophenone<smiles>C=C(c1ccc(OC)c(O)c1)c1cc(OC)c(OC)c(OC)c1</smiles>

3: isocombretastatin A-4

Figure 1. Structures of combretastatin and phenstatin derivatives 1-3.

Our strategy for the design of boron compounds is based on the properties that make them different from conventional biologically active compounds. ${ }^{10-15}$ Previously, we reported the synthesis of boronic acid-containing combretastatin A-4 analogue 1d. ${ }^{11,16}$ Herein, we report the synthesis and biological evaluation of boronic acid-containing phenstatin analogues (Figure 2).

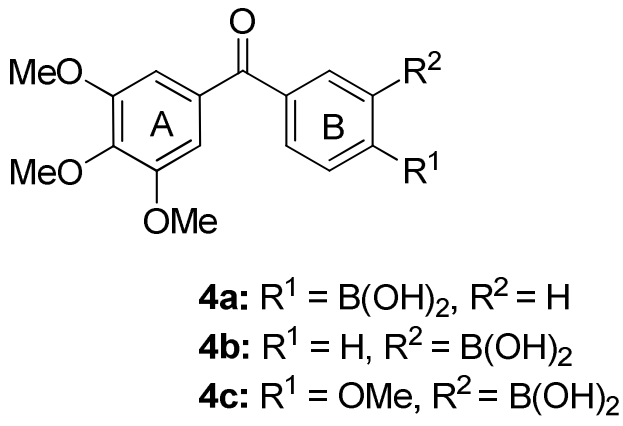

Figure 2. Design of boronic acid containing phenstatin analogues 4.

\section{Results and Discussion}

The boronic acid-containing phenstatin analogues $\mathbf{4 a}$ and $\mathbf{4 b}$ were synthesized from 3,4,5trimethoxybenzaldehyde and dihalobenzenes as shown in Scheme 1. The reaction of 1-bromo-4iodobenzene 5a with $n$-butyllithium in THF generated the 4-bromophenyllithium, which reacted with 3,4,5-trimethoxybenzaldehyde to give the corresponding carbinol $6 \mathbf{a}$ in $82 \%$ yield. ${ }^{17}$ In a similar manner, carbinol $\mathbf{6 b}$ was obtained from 1,3-diiodobenzene $\mathbf{5 b}$ in $65 \%$ yield. The carbinols $6 \mathbf{a}$ and $\mathbf{6 b}$ were converted into the corresponding ketones $7 \mathbf{a}^{17}$ and $7 \mathbf{b}$ using pyridinium 
chlorochromate (PCC) as an oxidizing agent and the ketal protection of the carbonyl groups was performed by treating with triomethyl orthoformate in methanol under acidic conditions to give $\mathbf{8 a}$ and $\mathbf{8 b}$ in $86 \%$ and $81 \%$ yields, respectively. Treatment of the ketals $\mathbf{8 a}$ and $\mathbf{8 b}$ with $n$ butyllithium and triisopropyl borate at $-78{ }^{\circ} \mathrm{C}$, followed by acidic hydrolysis, afforded the boronic acid-containing phenstatin analogues $\mathbf{4 a}$ and $\mathbf{4 b}$ in $37 \%$ and $72 \%$ yields in two steps, respectively.<smiles>[R]c1ccc(I)cc1[R]</smiles>

1) $n$-BuLi, THF

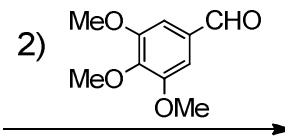

5a: $\mathrm{R}^{1}=\mathrm{Br}, \mathrm{R}^{2}=\mathrm{H}$

b: $R^{1}=H, R^{2}=$ I<smiles>[R]c1ccc(C(=O)c2cc(OC)c(OC)c(OC)c2)cc1[R]</smiles>

6a: $82 \%$

b: $65 \%$ 7a: $95 \%$

b: $92 \%$

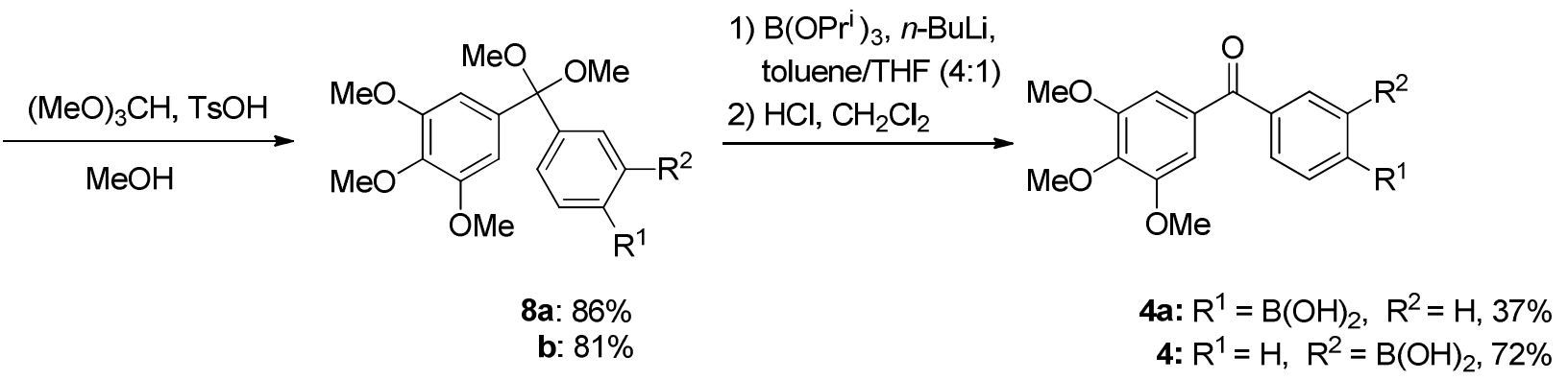

Scheme 1. Synthesis of boronic acid-containing phenstatin analogues $\mathbf{4 a}$ and $\mathbf{4 b}$.

We also synthesized boronic acid-containing phenstatin analogue $4 \mathbf{c}$ (Scheme 2). The reaction of 5-bromo-1,2,3-trimethoxybenzene with $n$-butyllithium in THF generated the corresponding aryllithium, which reacted with 3-bromo-4-methoxybenzaldehyde to give the carbinol 9 in $83 \%$ yield. The carbinol 9 underwent oxidation by treatment with PCC to give the corresponding ketone 10 in $94 \%$ yield. Protection of the carbonyl group in ketone $\mathbf{1 0}$ followed by introduction of boronic acid using $n$-butyllithium and triisopropyl borate at $-78{ }^{\circ} \mathrm{C}$ and deprotection of the ketal group under acidic conditions gave phenstatin analogue $4 \mathbf{c}$ in $52 \%$ yield in three steps.

We next examined inhibition of cell growth by the boronic acid analogues using B16 and 187 cell lines. The results are summarized in Table 1 . The benzophenones $\mathbf{4 a}$ and $\mathbf{4 b}$ exhibited $50 \%$ inhibition of cell growth at $0.85 \mu \mathrm{M}$ and $0.37 \mu \mathrm{M}$ concentrations toward B16 cells and at $3.1 \mu \mathrm{M}$ and $1.9 \mu \mathrm{M}$ concentrations toward 1-87 cells, respectively. The benzophenone $\mathbf{4 c}$, which has a boronic acid group at the meta position and a methoxy group at the para position, exhibited higher inhibition of cell growth against both cell lines and the $\mathrm{GI}_{50}$ values of $\mathbf{4 c}$ toward $\mathrm{B} 16$ and 
1-87 cells are $0.013 \mu \mathrm{M}$ and $0.087 \mu \mathrm{M}$, respectively. The boronic acid-containing combretastatin A-4 analogue 1d, which was previously synthesized as a tubulin polymerization inhibitor in our group $^{11}$ as well as Brown's group, independently, ${ }^{16}$ was more potent in cell growth inhibition. In all cases, B16 cells are more sensitive toward the synthesized boronic acids than 1-87 cells. ClogP (partition coefficient of a compound between octanol/water speculated by structure-based speculated program) values of each compound are also shown in Table 1. According to the ClogP values, one of the low inhibitory potency of $\mathbf{4 a}$ and $\mathbf{4 b}$ toward cell growth may be due to higher hydrophilicity, which could prevent the compounds from crossing the cell membrane.<smiles>COc1ccc(C(O)c2cc(C(O)c3cc(C(=O)c4cc(OC)c(OC)c(OC)c4)ccc3OC)cc(OC)c2OC)cc1OC</smiles><smiles>COc1ccc(C(OC)(OC)c2cc(OC)c(OC)c(OC)c2)cc1Br</smiles>

Scheme 2. Synthesis of boronic acid-containing phenstatin analogue 4c.

Table 1. Cell growth inhibition of boronic acid containing phenstatin analogues ${ }^{a}$

\begin{tabular}{|c|c|c|c|}
\hline \multirow{2}{*}{ compound } & \multicolumn{2}{|c|}{$\mathrm{GI}_{50} / \mu \mathrm{M}$} & \multirow{2}{*}{$\mathrm{C} \log \mathrm{P}^{d}$} \\
\hline & B16 cell ${ }^{b}$ & $1-87$ cell $^{c}$ & \\
\hline $4 a$ & 0.85 & 3.1 & 0.989 \\
\hline $4 b$ & 0.37 & 1.9 & 0.989 \\
\hline $4 c$ & 0.013 & 0.087 & 2.06 \\
\hline $1 d$ & 0.0062 & 0.013 & 3.50 \\
\hline
\end{tabular}

${ }^{a}$ The compounds were assayed at least three times and the $\mathrm{GI}_{50}$ values reported here are mean of an average of three experiments. ${ }^{b}$ Mouse B-16 melanoma cell line. ${ }^{c}$ Human lung carcinoma 1-87 cell line. ${ }^{d}$ Clog $\mathrm{P}$ values were speculated by using structure-based calculation program, ChemBioDraw Ultra ver. 12, PerkinElmer Inc.

We also examined the effects of the boronic acid-containing phenstatin analogues $\mathbf{4 a - c}$ on in vitro polymerization of tubulin. The tubulin was purified from porcine brains according to the Shelanski protocol ${ }^{18}$ with modification. ${ }^{19}$ Although it was reported that phenstatin significantly 
inhibits tubulin polymerization in vitro with an $\mathrm{IC}_{50}$ value of $1.1 \mu \mathrm{M}$, the boronic acid containing phenstatin analogues $4 \mathbf{a}-\mathbf{c}$ did not exhibited inhibition potency even at $100 \mu \mathrm{M}$. These results indicate that the current boronic acid containing phenstatin analogues, especially compound $\mathbf{4 c}$, possess significant inhibitory activity toward cell growth without interacting microtubule system.

\section{Conclusions}

We succeeded in synthesizing the boronic acid-containing phenstatin analogues $\mathbf{4 a - 4 c}$. The lithiation of the aromatic ring $\mathrm{B}$ of the phenstatin with $n$-butyllithium is essential for introduction of a boronic acid moiety in the molecules. Among the boronic acid-containing phenstatin analogues synthesized, compound $\mathbf{4 c}$, in which a hydroxyl group on the aromatic ring B of the phenstatin was replaced by a boronic acid, exhibited significant cell growth inhibition. Since the current synthesized compounds $\mathbf{4 a - 4 c}$ did not show any inhibition potency toward tubulin polymerization process in vitro, they are considered to inhibit cell growth by different mechanisms other than inhibition of the microtubule system.

\section{Experimental Section}

General. ${ }^{1} \mathrm{H}$ NMR and ${ }^{13} \mathrm{C}$ NMR spectra were measured on a JEOL JNM-AL 300 (300 MHz) or VARIAN UNITY-INOVA $400(400 \mathrm{MHz})$ spectrometers. Chemical shifts of ${ }^{1} \mathrm{H}$ NMR were expressed in parts per million downfield from $\mathrm{CDCl}_{3}$ as an internal standard $(\delta=7.24)$ in $\mathrm{CDCl}_{3}$ or from $\mathrm{CD}_{3} \mathrm{OD}$ as an internal standard $(\delta=3.35)$. Chemical shifts of ${ }^{13} \mathrm{C}$ NMR were expressed in parts per million downfield from $\mathrm{CDCl}_{3}$ as an internal standard $(\delta=77.0)$ in $\mathrm{CDCl}_{3}$ or from $\mathrm{CD}_{3} \mathrm{OD}$ as an internal standard $(\delta=49.3)$. Analytical thin layer chromatography (TLC) was performed on a glass plates (Merck Kieselgel $60 \mathrm{~F}_{254}$, layer thickness $0.2 \mathrm{~mm}$ or RP-18 $\mathrm{F}_{254 \mathrm{~s}}$, layer thickness $0.2 \mathrm{~mm}$ ). Visualization was accompanied by UV light $(254 \mathrm{~nm}), \mathrm{I}_{2}$ and $\mathrm{KMnO}_{4}$. Column chromatography was performed on silica gel (Merck Kieselgel 70-230 mesh). All reactions were carried out under an argon atmosphere using standard Schlenk techniques. Most chemicals and solvents were analytical grade and used without further purification.

4'-Bromo-3,4,5-trimethoxybenzhydrol (6a). To a mixture of 1-bromo-4-iodobenzene (5a) (8.5 $\mathrm{g}, 30 \mathrm{mmol})$ in THF (90 mL) was added $n$-butyllithium (1.6 M in hexane, $19 \mathrm{~mL}, 30 \mathrm{mmol})$ at $80^{\circ} \mathrm{C}$ under argon, and the mixture was stirred for $3 \mathrm{~h}$. A solution 3,4,5-trimethoxybenzaldehyde (5.9 g, $30 \mathrm{mmol})$ in THF $(60 \mathrm{~mL})$ was then added to the reaction mixture dropwise, and the reaction mixture allowed to warm to room temperature for $1 \mathrm{~h}$ with stirring. The reaction was quenched by saturated aqueous $\mathrm{NH}_{4} \mathrm{Cl}$ solution and the mixture was extracted with dichloromethane, dried over anhydrous $\mathrm{MgSO}_{4}$, and concentrated. Purification by silica gel column chromatography with hexane/ethyl acetate $(2: 1)$ gave $6 \mathbf{a}(8.7 \mathrm{~g}, 25 \mathrm{mmol}, 82 \%)$ as a 
colorless oil: ${ }^{1} \mathrm{H}$ NMR data were in agreement with those in the reported in the literature ${ }^{17}:{ }^{1} \mathrm{H}$ NMR (400 MHz, $\left.\mathrm{CDCl}_{3}\right) \delta 7.45(\mathrm{~d}, J=8.8 \mathrm{~Hz}, 2 \mathrm{H}), 7.25(\mathrm{~d}, J=8.8 \mathrm{~Hz}, 2 \mathrm{H}), 6.55(\mathrm{~s}, 2 \mathrm{H}), 5.71$ $(\mathrm{d}, J=3.2 \mathrm{~Hz}, 1 \mathrm{H}), 3.81(\mathrm{~s}, 6 \mathrm{H}), 3.81(\mathrm{~s}, 3 \mathrm{H}), 2.19(\mathrm{~d}, J=3.2 \mathrm{~Hz}, 1 \mathrm{H}) ;{ }^{13} \mathrm{C} \mathrm{NMR}(75 \mathrm{MHz}$; $\left.\mathrm{CDCl}_{3}\right): \delta 153.1,142.6,139.1,137.1,131.3,128.1,121.2,103.4,75.4,60.7,55.9$.

3'-Iodo-3,4,5-trimethoxybenzhydrol (6b). This compound was synthesized from 1,3diiodobenzene (5b) (3.3 g, $10 \mathrm{mmol})$ and 3,4,5-trimethoxybenzaldehyde (2.1 g, $11 \mathrm{mmol}) \mathrm{using}$ the procedure described for $\mathbf{6 a}$ to give $\mathbf{6 b}(2.6 \mathrm{~g}, 6.5 \mathrm{mmol}, 65 \%)$ as a colorless oil: ${ }^{1} \mathrm{H}$ NMR $\left(400 \mathrm{MHz} ; \mathrm{CDCl}_{3}\right) \delta 7.73(\mathrm{~s}, 1 \mathrm{H}), 7.57(\mathrm{~d}, J=8.0 \mathrm{~Hz}, 1 \mathrm{H}), 7.29(\mathrm{~d}, J=8.0 \mathrm{~Hz}, 1 \mathrm{H}), 7.04(\mathrm{t}, J=$ $8.0 \mathrm{~Hz}, 1 \mathrm{H}), 6.53(\mathrm{~s}, 2 \mathrm{H}), 5.64(\mathrm{~d}, J=2.8 \mathrm{~Hz}, 1 \mathrm{H}), 3.80(\mathrm{~s}, 6 \mathrm{H}), 3.80$ (s, 3H), 2.49 (d, J = 2.8 Hz, $1 \mathrm{H}) ;{ }^{13} \mathrm{C}$ NMR $\left(75 \mathrm{MHz} ; \mathrm{CDCl}_{3}\right) \delta 153.3,145.8,138.8,137.4,136.6,135.3,130.1,125.7,103.5$, 94.4, 75.5, 60.8, 56.1; HRMS (ESI, positive) $\mathrm{m} / z$ calcd. for $\mathrm{C}_{17} \mathrm{H}_{19} \mathrm{BrO}_{5}[\mathrm{M}+\mathrm{Na}]^{+}: 405.0314$, found: 405.0313

4'-Bromo-3,4,5-trimethoxybenzophenone (7a). To a mixture of pyridinium chlorochromate (PCC; $3.4 \mathrm{~g}, 16 \mathrm{mmol}$ ), sodium acetate (2.6 g) and $\mathrm{MgSO}_{4}(2.6 \mathrm{~g})$ in $\mathrm{CH}_{2} \mathrm{Cl}_{2}(50 \mathrm{~mL})$ was added a solution of $\mathbf{6 a}(3.7 \mathrm{~g}, 10 \mathrm{mmol})$ in $\mathrm{CH}_{2} \mathrm{Cl}_{2}(10 \mathrm{~mL})$ and the mixture was stirred at $\mathrm{rt}$ for $1 \mathrm{~d}$. After removal of solvents under reduced pressure, the residue was purified by column chromatography on silica gel with hexane/ethyl acetate (5:1) to yield the benzophenone $7 \mathbf{a}(3.5 \mathrm{~g}$, $9.9 \mathrm{mmol}, 95 \%)$ as a white solid: ${ }^{1} \mathrm{H}$ NMR data were in agreement with those in the reported in the literature 17: $\mathrm{mp} 101-103{ }^{\circ} \mathrm{C} ;{ }^{1} \mathrm{H}$ NMR $\left(300 \mathrm{MHz} ; \mathrm{CDCl}_{3}\right) \delta 7.64(\mathrm{~s}, 2 \mathrm{H}), 7.63(\mathrm{~s}, 2 \mathrm{H}), 7.01$ $(\mathrm{s}, 2 \mathrm{H}), 3.92(\mathrm{~s}, 3 \mathrm{H}), 3.85(\mathrm{~s}, 6 \mathrm{H}) ;{ }^{13} \mathrm{C} \mathrm{NMR}\left(75 \mathrm{MHz} ; \mathrm{CDCl}_{3}\right) \quad \delta$ 194.5, 152.9, 142.2, 136.5, $132.0,131.5,131.3,127.2,107.6,60.9,56.2$.

3'-Iodo-3,4,5-trimethoxybenzophenone (7b). This compound was synthesized from $\mathbf{6 b}(2.5 \mathrm{~g}$, $6.5 \mathrm{mmol})$ and PCC $(2.1 \mathrm{~g}, 9.7 \mathrm{mmol})$ using the procedure described for $7 \mathbf{a}$ to give $7 \mathbf{b}(2.3 \mathrm{~g}, 5.8$ mmol, 92\%) as a white solid: $\mathrm{mp} 113-115{ }^{\circ} \mathrm{C} ;{ }^{1} \mathrm{H} \mathrm{NMR}\left(400 \mathrm{MHz} ; \mathrm{CDCl}_{3}\right) \delta 8.11(\mathrm{t}, J=7.6 \mathrm{~Hz}$, $1 \mathrm{H}), 7.89(\mathrm{dq}, J=7.6,1.6 \mathrm{~Hz}, 1 \mathrm{H}), 7.71(\mathrm{dq}, J=7.6,1.6 \mathrm{~Hz}, 1 \mathrm{H}), 7.21(\mathrm{t}, J=7.6 \mathrm{~Hz}, 1 \mathrm{H}), 7.01$ $(\mathrm{s}, 2 \mathrm{H}), 3.93(\mathrm{~s}, 3 \mathrm{H}), 3.86(\mathrm{~s}, 6 \mathrm{H}) ;{ }^{13} \mathrm{C} \mathrm{NMR}\left(75 \mathrm{MHz}, \mathrm{CDCl}_{3}\right) \quad \delta$ 194.0, 153.0, 142.5, 141.0, 139.7, 138.6, 131.8, 129.9, 128.9, 107.8, 94.0, 61.0, 56.3; HRMS (ESI, positive) $\mathrm{m} / \mathrm{z}$ calcd. for $\mathrm{C}_{16} \mathrm{H}_{17} \mathrm{IO}_{4}[\mathrm{M}+\mathrm{Na}]^{+}:$423.0069, found: 423.0066

4'-Bromo-3,4,5-trimethoxybenzophenone dimethyl acetal (8a). To a mixture of 7a (1.1 g, 3.1 $\mathrm{mmol})$ and $p$-toluenesulfonic acid monohydrate $(0.030 \mathrm{~g}, 0.16 \mathrm{mmol})$ in $\mathrm{MeOH}(15 \mathrm{~mL})$ was added trimethoxymethane $(0.40 \mathrm{~mL}, 3.7 \mathrm{mmol})$ and the mixture was stirred under reflux for $8 \mathrm{~h}$. Sodium methoxide $(28 \% \mathrm{w} / \mathrm{w}$ in methanol; $0.31 \mathrm{~mL}, 1.6 \mathrm{mmol})$ was added to the reaction mixture, which was stirred for further 5 min and then the solvents were evaporated. Saturated aq. $\mathrm{NaHCO}_{3}$ solution was added and the mixture was extracted with $\mathrm{CH}_{2} \mathrm{Cl}_{2}$, dried over anhydrous $\mathrm{MgSO}_{4}$, and concentrated. The resulting solid was washed with cold $\mathrm{MeOH}$ to afford $8 \mathbf{a}(1.0 \mathrm{~g}$, $2.6 \mathrm{mmol}, 86 \%)$ as a white solid. This solid was pure enough to perform the next step: $\mathrm{mp} 125$ $127{ }^{\circ} \mathrm{C} ;{ }^{1} \mathrm{H}$ NMR $\left(400 \mathrm{MHz} ; \mathrm{CDCl}_{3}\right) \delta 7.41(\mathrm{~d}, J=8.4 \mathrm{~Hz}, 2 \mathrm{H}), 7.35(\mathrm{~d}, J=8.4 \mathrm{~Hz}, 2 \mathrm{H}), 6.67(\mathrm{~s}$, 2H), $3.80(\mathrm{~s}, 9 \mathrm{H}), 3.09(\mathrm{~s}, 6 \mathrm{H}) ;{ }^{13} \mathrm{C} \mathrm{NMR}\left(75 \mathrm{MHz} ; \mathrm{CDCl}_{3}\right) \delta 152.8,141.3,137.4,137.2,131.0$, 128.5, 121.6, 103.9, 102.3, 60.6, 56.0, 49.3; HRMS (ESI, positive) $\mathrm{m} / z$ calcd. for $\mathrm{C}_{18} \mathrm{H}_{21} \mathrm{BrO}_{5}$ $[\mathrm{M}+\mathrm{Na}]^{+}: 419.0470$, found: 419.0472 
3'-Iodo-3,4,5-trimethoxybenzophenone dimethyl acetal $(\mathbf{8 b})$. This compound was synthesized from $7 \mathbf{b}(1.2 \mathrm{~g}, 3.0 \mathrm{mmol})$ and trimethoxymethane $(0.39 \mathrm{~mL}, 3.6 \mathrm{mmol})$ using the procedure described for $\mathbf{8 a}$ to give $\mathbf{8 b}(1.1 \mathrm{~g}, 2.4 \mathrm{mmol}, 81 \%)$ as a white solid: mp $113-115{ }^{\circ} \mathrm{C} ;{ }^{1} \mathrm{H}$ NMR $\left(400 \mathrm{MHz} ; \mathrm{CDCl}_{3}\right): \delta 7.88(\mathrm{~s}, 1 \mathrm{H}), 7.56(\mathrm{~d}, J=7.6 \mathrm{~Hz}, 1 \mathrm{H}), 7.38(\mathrm{~d}, J=7.6 \mathrm{~Hz}, 1 \mathrm{H}), 7.01(\mathrm{t}, J=$ $7.6 \mathrm{~Hz}, 1 \mathrm{H}), 6.68(\mathrm{~s}, 2 \mathrm{H}), 3.80(\mathrm{~s}, 9 \mathrm{H}), 3.10(\mathrm{~s}, 6 \mathrm{H}) ;{ }^{13} \mathrm{C} \mathrm{NMR}\left(75 \mathrm{MHz} ; \mathrm{CDCl}_{3}\right): \delta 152.9$, 144.6, 137.3, 137.3 136.6, 135.6, 129.8, 126.2, 104.0, 101.9, 94.1, 60.7, 56.1, 49.4; HRMS (ESI, positive) $\mathrm{m} / \mathrm{z}$ calcd. for $\mathrm{C}_{18} \mathrm{H}_{21} \mathrm{IO}_{5}[\mathrm{M}+\mathrm{Na}]^{+}: 467.0331$, found: 467.0331

4'-(Dihydroxylboryl)-3,4,5-trimethoxybenzophenone (4a). To a mixture of 8a (1.0 g, 2.6 $\mathrm{mmol})$ and triisopropyl borate $(0.73 \mathrm{~mL}, 3.1 \mathrm{mmol})$ in THF $(2 \mathrm{~mL})$ and toluene $(8 \mathrm{~mL})$ was added $n$-butyllithium $(1.6 \mathrm{M}$ in hexane; $1.8 \mathrm{~mL}, 2.9 \mathrm{mmol})$ dropwise at $-78{ }^{\circ} \mathrm{C}$. The mixture was stirred for $1.5 \mathrm{~h}$ at $-78{ }^{\circ} \mathrm{C}$ and allowed to warm to $-20{ }^{\circ} \mathrm{C}$ for $30 \mathrm{~min}$ with stirring. The reaction was quenched by aqueous $\mathrm{HCl}$ solution $(1 \mathrm{~N})$ and the mixture was extracted with $\mathrm{CH}_{2} \mathrm{Cl}_{2}$, dried over anhydrous $\mathrm{MgSO}_{4}$, and concentrated. Purification by column chromatography on silica gel with hexane/EtOAc (2/1) gave 8a, which was dissolved in $\mathrm{CH}_{2} \mathrm{Cl}_{2}(4 \mathrm{~mL})$ and conc. $\mathrm{HCl}(4 \mathrm{~mL})$ was added. The mixture was stirred for $2 \mathrm{~h}$ and then diluted with water. The aqueous mixture was extracted with EtOAc and the organic layer was neutralized with saturated aqueous $\mathrm{NaHCO}_{3}$ solution. The organic layer was separated, dried over anhydrous $\mathrm{MgSO}_{4}$, and concentrated. The resulting white solid was washed with co-solvent of ether and hexane to afford $\mathbf{4 a}(0.31 \mathrm{~g}, 0.97$ mmol, $37 \%$ in 2 steps) as a white solid: $\mathrm{mp} 134-136{ }^{\circ} \mathrm{C} ;{ }^{1} \mathrm{H}$ NMR $\left(400 \mathrm{MHz} ; \mathrm{CD}_{3} \mathrm{OD}\right): \delta 7.93$ $(\mathrm{s}, 2 \mathrm{H}), 7.77(\mathrm{~s}, 2 \mathrm{H}), 7.13(\mathrm{~s}, 2 \mathrm{H}), 3.90(\mathrm{~s}, 3 \mathrm{H}), 3.89(\mathrm{~s}, 6 \mathrm{H}) ;{ }^{13} \mathrm{C}$ NMR $\left(75 \mathrm{MHz} ; \mathrm{CD}_{3} \mathrm{OD}\right): \delta$ 197.5, 154.0, 143.3, 140.0, 134.5, 133.6, 129.5, 108.8, 61.2, 56.7, 49.9. Anal. calcd for $\mathrm{C}_{16} \mathrm{H}_{17} \mathrm{BO}_{6}$ : C, 60.79; H, 5.42. found: C, 60.53; H, 5.29.

3'-(Dihydroxylboryl)-3,4,5-trimethoxybenzophenone (4b). This compound was synthesized from $8 \mathbf{b}(0.60 \mathrm{~g}, 1.4 \mathrm{mmol})$ and triisopropyl borate $(0.38 \mathrm{~mL}, 1.6 \mathrm{mmol})$ using the procedure described for $\mathbf{4 a}$ to give $\mathbf{4 b}(0.31 \mathrm{~g}, 0.98 \mathrm{mmol}, 72 \%)$ as a white solid: mp $91-93{ }^{\circ} \mathrm{C} ;{ }^{1} \mathrm{H} \mathrm{NMR}$ $\left(400 \mathrm{MHz} ; \mathrm{CD}_{3} \mathrm{OD}\right): \delta 8.20(\mathrm{bs}, 1 \mathrm{H}), 8.05(\mathrm{bd}, J=8.0 \mathrm{~Hz}, 1 \mathrm{H}), 7.84(\mathrm{~d}, J=8.0 \mathrm{~Hz}, 1 \mathrm{H}), 7.55(\mathrm{t}$, $J=8.0 \mathrm{~Hz}, 1 \mathrm{H}), 7.13(\mathrm{~s}, 2 \mathrm{H}), 3.91(\mathrm{~s}, 3 \mathrm{H}), 3.89(\mathrm{~s}, 6 \mathrm{H}) ;{ }^{13} \mathrm{C} \mathrm{NMR}\left(75 \mathrm{MHz} ; \mathrm{CD}_{3} \mathrm{OD}\right): \delta 197.9$, $154.3,143.5,138.9,138.2,136.4,133.9,132.4,128.7,109.0,61.2,56.7$. Anal. calcd for $\mathrm{C}_{16} \mathrm{H}_{17} \mathrm{BO}_{6}$ : C, 60.79; H, 5.42. found: $\mathrm{C}, 60.57 ; \mathrm{H}, 5.31$.

3'-Bromo-3,4,4',5-tetramethoxybenzhydrol (9). To a mixture of 5-bromo-1,2,3trimethoxybenzene $(1.3 \mathrm{~g}, 5.1 \mathrm{mmol})$ in THF $(15 \mathrm{~mL})$ was added $n$-butyllithium $(1.6 \mathrm{M}$ in hexane, $3.3 \mathrm{~mL}, 5.3 \mathrm{mmol}$ ) at $-80^{\circ} \mathrm{C}$ under argon dropwise, and the mixture was stirred for $1.5 \mathrm{~h}$. A solution 3-bromo-4-methoxybenzaldehyde $(1.2 \mathrm{~g}, 5.3 \mathrm{mmol})$ in THF $(10 \mathrm{~mL})$ was then added to the reaction mixture dropwise for $1 \mathrm{~h}$, and the reaction mixture allowed to warm to $0{ }^{\circ} \mathrm{C}$ for 1 $\mathrm{h}$ with stirring. The reaction was quenched by saturated aqueous $\mathrm{NH}_{4} \mathrm{Cl}$ solution and the mixture was extracted with $\mathrm{CH}_{2} \mathrm{Cl}_{2}$, dried over anhydrous $\mathrm{MgSO}_{4}$, and concentrated. Purification by silica gel column chromatography with hexane/EtOAc (2:1) gave 9 (1.6 g, $4.2 \mathrm{mmol}, 83 \%)$ as a colorless oil: ${ }^{1} \mathrm{H}$ NMR (400 MHz; $\left.\mathrm{CDCl}_{3}\right): \delta 7.55(\mathrm{~d}, J=2.0 \mathrm{~Hz}, 1 \mathrm{H}), 7.24(\mathrm{dd}, J=8.4,2.0 \mathrm{~Hz}$, $1 \mathrm{H}), 6.84(\mathrm{~d}, J=8.4 \mathrm{~Hz}, 1 \mathrm{H}), 6.55(\mathrm{~s}, 2 \mathrm{H}), 5.68(\mathrm{~d}, J=3.2 \mathrm{~Hz}, 1 \mathrm{H}), 3.87(\mathrm{~s}, 3 \mathrm{H}), 3.82(\mathrm{~s}, 6 \mathrm{H})$, $3.81(\mathrm{~s}, 3 \mathrm{H}), 2.23(\mathrm{~d}, J=3.2 \mathrm{~Hz}, 1 \mathrm{H}) ;{ }^{13} \mathrm{C} \mathrm{NMR}\left(75 \mathrm{MHz} ; \mathrm{CDCl}_{3}\right): \delta 155.0,153.1,139.2,137.3$, 
137.0, 131.4, 126.6, 111.6, 111.4, 103.2, 75.0, 60.7, 56.1, 55.9; HRMS (ESI, positive) $\mathrm{m} / \mathrm{z}$ calcd. for $\mathrm{C}_{17} \mathrm{H}_{19} \mathrm{BrO}_{5}[\mathrm{M}+\mathrm{Na}]^{+}: 405.0314$, found: 405.0313

3'-Bromo-3,4,4',5-tetramethoxybenzophenone (10). To a mixture of PCC $(1.3 \mathrm{~g}, 5.9 \mathrm{mmol})$, sodium acetate $(1.0 \mathrm{~g})$ and $\mathrm{MgSO}_{4}(1.0 \mathrm{~g})$ in dichloromethane $(16 \mathrm{~mL})$ was added a solution of 9 $(1.5 \mathrm{~g}, 3.9 \mathrm{mmol})$ in dichloromethane $(16 \mathrm{~mL})$ and the mixture was stirred at room temperature for 2 days. After removal of solvents under reduced pressure, the residue was purified by column chromatography on silica gel with hexane/ethyl acetate (2:1) to yield the benzophenone $\mathbf{1 0}(1.4 \mathrm{~g}$, $3.7 \mathrm{mmol}, 94 \%)$ as a white solid: $\mathrm{mp} 105-107{ }^{\circ} \mathrm{C} ;{ }^{1} \mathrm{H} \mathrm{NMR}\left(400 \mathrm{MHz} ; \mathrm{CDCl}_{3}\right): \delta 8.05(\mathrm{~d}, J=$ $2.4 \mathrm{~Hz}, 1 \mathrm{H}), 7.76(\mathrm{dd}, J=8.4,2.4 \mathrm{~Hz}, 1 \mathrm{H}), 6.98(\mathrm{~s}, 2 \mathrm{H}), 6.95(\mathrm{~d}, J=8.4 \mathrm{~Hz}, 1 \mathrm{H}), 3.97(\mathrm{~s}, 3 \mathrm{H})$, $3.92(\mathrm{~s}, 3 \mathrm{H}), 3.86(\mathrm{~s}, 6 \mathrm{H}) ;{ }^{13} \mathrm{C}$ NMR $\left(75 \mathrm{MHz} ; \mathrm{CDCl}_{3}\right): \delta 193.1,159.0,152.7,141.7,135.3$, 132.5, 131.2, 131.1, 111.6, 110.8, 107.4, 61.0, 56.5, 56.3; HRMS (ESI, positive) $\mathrm{m} / z$ calcd. for $\mathrm{C}_{17} \mathrm{H}_{17} \mathrm{BrO}_{5}[\mathrm{M}+\mathrm{Na}]^{+}:$403.157, found: 403.0161

3'-(Dihydroxylboryl)-3,4,4',5-tetramethoxybenzophenone (4c). To a mixture of 10 (0.99 g, $2.6 \mathrm{mmol})$ and $p$-toluenesulfonic acid monohydrate $(0.025 \mathrm{~g}, 0.13 \mathrm{mmol})$ in $\mathrm{MeOH}(13 \mathrm{~mL})$ was added trimethoxymethane $(0.40 \mathrm{~mL}, 3.7 \mathrm{mmol})$ and the mixture was stirred under reflux for $4 \mathrm{~h}$. Sodium methoxide (28\%w/w in $\mathrm{MeOH} ; 0.31 \mathrm{~mL}, 13 \mathrm{mmol}$ ) was added to the reaction mixture, which was stirred for further $5 \mathrm{~min}$ and then the solvents were evaporated. Saturated aqueous $\mathrm{NaHCO}_{3}$ solution was added and the mixture was extracted with $\mathrm{CH}_{2} \mathrm{Cl}_{2}$, dried over anhydrous $\mathrm{MgSO}_{4}$, and concentrated. The resulting dimethyl ketal was dissolved in THF (2.6 mL) and toluene $(10 \mathrm{~mL})$, and triisopropyl borate $(0.73 \mathrm{~mL}, 3.1 \mathrm{mmol})$ wad added. $n$-Butyllithium $(1.6 \mathrm{M}$ in hexane; $1.9 \mathrm{~mL}, 3.0 \mathrm{mmol}$ ) was added dropwise at $-78{ }^{\circ} \mathrm{C}$ to this mixture, which was stirred for $1.5 \mathrm{~h}$ at $-78{ }^{\circ} \mathrm{C}$ and allowed to warm to $-20{ }^{\circ} \mathrm{C}$ for $30 \mathrm{~min}$ with stirring. The reaction was quenched by aqueous $\mathrm{HCl}$ solution $(1 \mathrm{~N})$ and the mixture was extracted with $\mathrm{CH}_{2} \mathrm{Cl}_{2}$, dried over anhydrous $\mathrm{MgSO}_{4}$, and concentrated. The resulting solid was dissolved in $\mathrm{CH}_{2} \mathrm{Cl}_{2}(4 \mathrm{~mL})$ and conc. $\mathrm{HCl}(4 \mathrm{~mL})$ was added. The mixture was stirred for $2 \mathrm{~h}$ and then diluted with water. The aqueous mixture was extracted with EtOAc and the organic layer was neutralized with saturated aqueous $\mathrm{NaHCO}_{3}$ solution. The organic layer was separated, dried over anhydrous $\mathrm{MgSO}_{4}$, and concentrated. Purification by column chromatography on silica gel with $\mathrm{CH}_{2} \mathrm{Cl}_{2} / \mathrm{EtOH}$ (100:1) gave $4 \mathrm{c}(0.44 \mathrm{~g}, 1.3 \mathrm{mmol}, 43 \%$ in 3 steps $)$ as a white solid: $\mathrm{mp} 160-162{ }^{\circ} \mathrm{C} ;{ }^{1} \mathrm{H}$ NMR $(400 \mathrm{MHz}$; $\left.\mathrm{CDCl}_{3}\right): \delta 8.33(\mathrm{~d}, J=2.4 \mathrm{~Hz}, 1 \mathrm{H}), 7.99(\mathrm{dd}, J=8.8,2.4 \mathrm{~Hz}, 1 \mathrm{H}), 7.03(\mathrm{~s}, 2 \mathrm{H}), 7.01(\mathrm{~d}, J=8.8$ $\mathrm{Hz}, 1 \mathrm{H}), 5.76(\mathrm{~s}, 2 \mathrm{H}), 4.00(\mathrm{~s}, 3 \mathrm{H}), 3.92(\mathrm{~s}, 3 \mathrm{H}), 3.86(\mathrm{~s}, 6 \mathrm{H}) ;{ }^{13} \mathrm{C}$ NMR $\left(75 \mathrm{MHz} ; \mathrm{CDCl}_{3}\right): \delta$ 194.5, 167.5, 152.8, 141.8, 139.6, 135.3, 132.9, 130.8, 110.0, 107.6, 60.9, 56.3, 56.0. Anal. calcd for $\mathrm{C}_{17} \mathrm{H}_{19} \mathrm{BO}_{7}$ : C, 58.99; H, 5.53. found: C, 58.89; H, 5.45.

\section{Acknowledgements}

We thank Professor T. Haga (Gakushuin University) for useful suggestions on the tubulin polymerization inhibition assay. 


\section{References}

1. Pettit, G. R.; Cragg, G. M.; Herald, D. L.; Schmidt, J. M.; Lohavanijaya, P. Can. J. Chem. 1982, 60, 1374.

2. McGown, A.; Fox, B. Canc. Chemother. Pharmacol. 1990, 26, 79.

3. Pettit, G. R.; Toki, B.; Herald, D. L.; Verdier-Pinard, P.; Boyd, M. R.; Hamel, E.; Pettit, R. K. J. Med. Chem. 1998, 41, 1688.

4. Pettit, G. R.; Singh, S. B.; Boyd, M. R.; Hamel, E.; Pettit, R. K.; Schmidt, J. M.; Hogan, F. J. Med. Chem. 1995, 38, 1666.

5. Liou, J.-P.; Chang, C.-W.; Song, J.-S.; Yang, Y.-N.; Yeh, C.-F.; Tseng, H.-Y.; Lo, Y.-K.; Chang, Y.-L.; Chang, C.-M.; Hsieh, H.-P. J. Med. Chem. 2002, 45, 2556.

6. Liou, J.-P.; Chang, J.-Y.; Chang, C.-W.; Chang, C.-Y.; Mahindroo, N.; Kuo, F.-M.; Hsieh, H.-P. J. Med. Chem. 2004, 47, 2897.

7. Messaoudi, S.; Tréuier, B.; Hamze, A.; Provot, O.; Peyrat, J.-F.; De Losada, J. R.; Liu, J.M.; Bignon, J.; Wdzieczak-Bakala, J.; Thoret, S.; Dubois, J. 1.; Brion, J.-D.; Alami, M. J. Med. Chem. 2009, 52, 4538.

8. $\quad$ Koehler, K. A.; Lienhard, G. E. Biochemistry 1971, 10, 2477.

9. Trippier, P. C.; McGuigan, C. Med. Chem. Comm. 2010, 1, 1838.

10. Asano, T.; Nakamura, H.; Uehara, Y.; Yamamoto, Y. ChemBioChem 2004, 5, 483.

11. Nakamura, H.; Kuroda, H.; Saito, H.; Suzuki, R.; Yamori, T.; Maruyama, K.; Haga, T. Chem. Med. Chem 2006, 1, 729.

12. Ban, H. S.; Usui, T.; Nabeyama, W.; Morita, H.; Fukuzawa, K.; Nakamura, H. Org. Biomol. Chem. 2009, 7, 4415.

13. Nakamura, H.; Watanabe, M.; Ban, H. S.; Nabeyama, W.; Asai, A. Bioorg. Med. Chem. Lett. 2009, 19, 3220.

14. Nakamura, H.; Horikoshi, R.; Usui, T.; Ban, H. S. Med. Chem. Comm. 2010, 1, 282-286.

15 Shimizu, K.; Maruyama, M.; Yasui, Y.; Minegishi, H.; Ban, H. S.; Nakamura, H. Bioorg. Med. Chem. Lett. 2010, 20, 1453.

16. Kong, Y.; Grembecka, J.; Edler, M. C.; Hamel, E.; Mooberry, S. L.; Sabat, M.; Rieger, J.; Brown, M. L. Chem. Biol. 2005, 12, 1007.

17. Lee, J.; Kim, S. J.; Choi, H.; Kim, Y. H.; Lim, I. T.; Yang, H.-m.; Lee, C. S.; Kang, H. R.; Ahn, S. K.; Moon, S. K.; Kim, D.-H.; Lee, S.; Choi, N. S.; Lee, K. J. J. Med. Chem. 2010, $53,6337$.

18. Shelanski, M. L.; Gaskin, F.; Cantor, C. R. Proc. Natl. Acad. Sci. USA 1973, 70, 765.

19. Haga, T.; Abe, T.; Kurokawa, M. FEBS Lett. 1974, 39, 291. 